\title{
Persaeus on Prodicus on the Gods' Existence and Nature
}

Another Attempt Based on a New Reconstruction of Philodemus'Account

\section{Christian Vassallo}

\section{OpenEdition}

\section{Journals}

Electronic version

URL: https://journals.openedition.org/philosant/1030

DOI: $10.4000 /$ philosant.1030

ISSN: 2648-2789

\section{Publisher}

Éditions Vrin

\section{Printed version}

Date of publication: 1 November 2018

Number of pages: 153-167

ISBN: 978-2-7574-2372-1

ISSN: 1634-4561

\section{Electronic reference}

Christian Vassallo, "Persaeus on Prodicus on the Gods' Existence and Nature", Philosophie antique [Online], 18 | 2018, Online since 01 November 2019, connection on 03 December 2022. URL: http:// journals.openedition.org/philosant/1030 ; DOI: https://doi.org/10.4000/philosant.1030

\section{(c) (†) $\ominus$}

Creative Commons - Attribution-NonCommercial-NoDerivatives 4.0 International - CC BY-NC-ND 4.0 https://creativecommons.org/licenses/by-nc-nd/4.0/ 


\section{PERSAEUS ON PRODICUS ON THE GODS' EXISTENCE AND NATURE \\ Another Attempt Based on a New Reconstruction of Philodemus'Account}

Christian VASSALLO

University of Notre Dame / University of Calabria

christian.vassallo@unical.it

RÉSUMÉ. Cet article analyse le problème de l'« athéisme » prétendu de Prodicos. Un ré-examen des sources à notre disposition et, surtout, une nouvelle reconstruction des témoignages fournis par le Sur la piété de Philodème, dont l'un est consacré à la théologie du stoïcien Persaïos, démontre que Prodicos n'était pas un athée mais un critique virulent de la conception traditionnelle des dieux.

Summary. This paper analyzes the problem of the alleged 'atheism' of Prodicus. A re-examination of the sources at our disposal and, above all, a new reconstruction of the testimonia handed down by Philodemus' On Piety, one of which is devoted to the theology of the Stoic Persaeus, demonstrate that Prodicus was not an atheist but only a scathing critic of the traditional conception of the gods.

Philosophie antique, ${ }^{\circ} 18$ (2018), 153-168 

Both in the ancient tradition and in modern studies, Prodicus' alleged atheism has primarily been justified on the basis of a questionable syllogism*: one who considers the gods worshipped by men a symbol of all that is useful to their (biological and political) lives should necessarily deny the existence of the gods and, more generally, the existence of any kind of divine being. We can infer this argument theoretically from a series of ancient sources. ${ }^{1}$ However, of all these various sources, only Sextus Empiricus explicitly counts

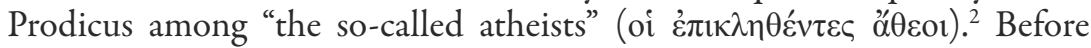
Sextus, Epicurus, in Book 12 of his On Nature, had included Prodicus on the most ancient list of 'atheists' known to us. ${ }^{3}$ This piece of information can be read in Philodemus' On Piety. ${ }^{4}$ In this passage, Epicurus is said to have accused Prodicus, Diagoras, and Critias of madness. This accusation would have been motivated by their tendency to change the names of the gods

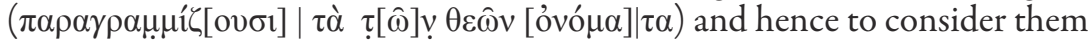

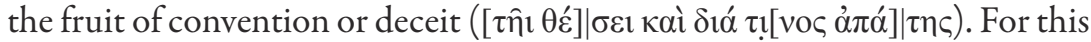
reason - Philodemus says - Epicurus numbered them among those who eliminate the divine from the things in existence. I, however, think it is more

* I wish to thank Jaap Mansfeld for reading this paper before its submission, as well as Stavros Kouloumentas, who, thanks to the kind mediation of Jean-Baptiste Gourinat, allowed me to look at his paper on Prodicus in this volume in advance and to realize with pleasure that, although we approach the topic from different perspectives, the conclusions of our research essentially converge.

1. Prodicus test. 71-78 Mayhew 2011. Most of these testimonia have been already collected in DK 84 B 5.

2. Sextus M. IX 50-52 (= test. 75 Mayhew), where Prodicus is mentioned along with Euhemerus, Diagoras, and Theodorus. No trace of Prodicus appears in the Atheistenkatalog transmitted by Ps.-Plutarch, which Hermann Diels used for the reconstruction of the theo-

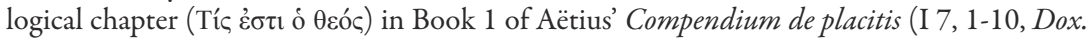
Graec., p. 297-301 = Ps.-Plut., Plac. 880D7-881D8). Cf. Runia 1996; Vassallo forthcoming a. See Mansfeld 2013 as well.

3. Long \& Sedley 1987 II, 151; Obbink 1996 p. 351.

4. Philodemus Piet., PHerc. 1077, col. 19 Obbink. 
reasonable to understand Philodemus' words as referring to the gods and not to the divine. As a matter of fact, I would reconstruct lines 3-5 of the column

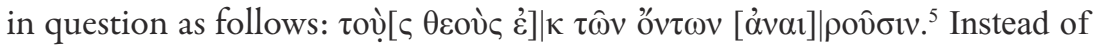

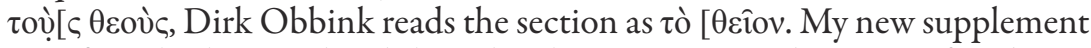
significantly changes the philosophical perspective on this piece of evidence. Removing the divine means excluding any form of theology, tout court, while removing the gods means giving no value only to the divinities worshipped by common men, but, in some way, leaves the possibility that the divine exists in some form. The divine should have a character absolutely different from that which common people ascribe to the gods. However, the philosopher is unable to do anything with this idea of the divine except ascertain its (unique and) unknown nature. This interpretation is supported, among other things, by Philodemus' reference to Antisthenes with regard to the $\pi \alpha \rho \alpha \gamma \rho \alpha \mu \mu$ í $\varepsilon \mathrm{\varepsilon v}$ performed by Prodicus, Diagoras, and Critias. Antisthenes - as Philodemus says in another passage of $O n$ Piety (and along with him, other sources testify to this fact as well ${ }^{6}$ ) — was not an atheist. In his Physics ${ }^{7}$ he maintained that the existence of many gods is affirmed only by convention ( $\kappa \alpha \tau \grave{\alpha}$ vó $\mu \mathrm{ov}$ ),

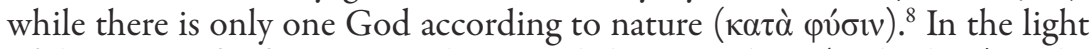
of this piece of information, what is said about Prodicus (and others) in the Herculanean testimonium in question cannot be projected, in my view, onto either an 'atheistic' (as Robert Mayhew supposes ${ }^{9}$ ) or a (Protagorean-like) 'agnostic' position. Rather, it would be a 'theistic' and (partially) 'sceptical' solution, which seems to reflect a philosophical awareness of the limits of language - if it is possible to make this claim without running the risk of anachronism. Citing Ludwig Wittgenstein, we could say: wovon man nicht sprechen kann, darüber muss man schweigen! ${ }^{10}$

If this is true, we can read the other testimonia to Prodicus handed down by Philodemus' On Piety in another way as well. I believe that they cannot support a reading of Prodicus' atheism. ${ }^{11}$ The sophist, instead, would have been engaged in denouncing the 'epistemological' mistake of human faith in (false) gods. In other words, men would be unable to know the true God

5. The testimonium is handed down by two Neapolitan apographs. I have checked them again and in the first one $\left(N^{I}\right)$ I read $\tau o v\left[\ldots . . .\right.$, ; as for $N^{2}(\tau \circ[)$, the supplement I propose seems not to be spatio longius, considering that the number of letters in each line goes from a minimum of $12 / 13$ to a maximum of $16 / 17$.

6. Cf. SSR V A 180 (= Giannantoni 1990).

7. See Giannantoni 1990 IV, p. 251-253.

8. Philodemus Piet., PHerc. 1428, col. 335 Vassallo (= fr. 21 Schober $)=S S R$ V A 179. On Antisthenes' theology I refer to Brancacci 1985-1986.

9. Mayhew 2011 p. 176.

10. Wittgenstein 1995 p. 109 (prop. 7).

11. The same conclusions are reached by Sedley 2013 p. 330-331 and Stavros Kouloumentas in his contribution to this volume p. 127-152. 
through reason and, prey as they are to emotion (especially fear), would profess that they believe in divinities that are only the fruit of their fantasy and, above all, mirror their physical and material needs. We can draw such a conclusion from the first testimonium to Prodicus in PHerc. 1428 (T1). This testimonium occurs at the end of a large 'Presocratic section' in the last part of Philodemus' On Piety, where all the ancient theologies, from the Milesians to the Stoics, are systematically exposed and criticized. It is remarkable that no hint of Prodicus can be found in Velleius' excursus of Cicero's On the Nature of the Gods, ${ }^{12}$ which represents a parallel version of the doxographical catalogue transmitted by PHerc. 1428. A lacuna of this kind, which occurs in Heraclitus' case as well, ${ }^{13}$ could be due to various reasons. I would be inclined to believe that Cicero and Philodemus handled partially different sources and that they used their common source (or sources) with different aims, due in part to the contrasting structures of the two works in question. A plausible, but not quite convincing, hypothesis suggests that Cicero (probably by mistake) inserted the account of Prodicus' theology into the one concerning Persaeus. $^{14}$

Below, I provide my reconstruction of this testimonium (PHerc. 1428, col. 333 Vassallo $=$ fr. 19 Schober), where at least two aspects are noteworthy: a) in the first part of the remnants of the column a new occurrence of the triad Prodicus, Diagoras, and Critias could be restored: the first two philosophers seem to maintain that the gods (if they really exist) are good in nature $;^{15} \mathrm{~b}$ ) in the last section (on the basis of my interpretation and translation of the passage ${ }^{16}$ ) not the gods tout court, but the gods in whom men profess to trust are said not to exist. Thus, the main idea that emerges from this piece of evidence is that common people are not able to know the true nature of the divinity, rather than the idea that God does not exist. That is to say, all traditional divine genealogies are false and not philosophically grounded.

T1. Philodemus Piet., PHerc. 1428, col. 333 Vassallo (= fr. 19 Schober)

$$
\begin{aligned}
& \text { desunt versus fere } 13
\end{aligned}
$$

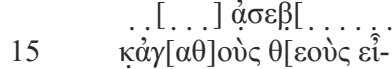

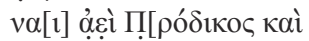

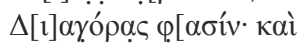

12. Cicero ND I 10 [25]-15 [41], from Thales to Diogenes of Babylon.

13. $C f$. Vassallo forthcoming b.

14. Cicero ND I 15 [38]. Thus Henrichs 1975 p. 113-114 and Mayhew 2011 p. 185-186. See the remarks in Winiarczyk 1991 p. 10 as well.

15. In this regard a comparison with Xenophon Mem. II 1, 21-34 (= DK 84 B 2) proves interesting.

16. For other interpretations and different translations, see Henrichs 1975 p. 107-115; Henrichs 1976; Henrichs 1984; Mayhew 2011 p. 46-47 and p. 183-185. 
$\mathrm{K} \rho[1] \tau[i] \alpha[\varsigma, \theta] \varepsilon \grave{v} v \varphi[\eta \sigma \mathrm{v} v$

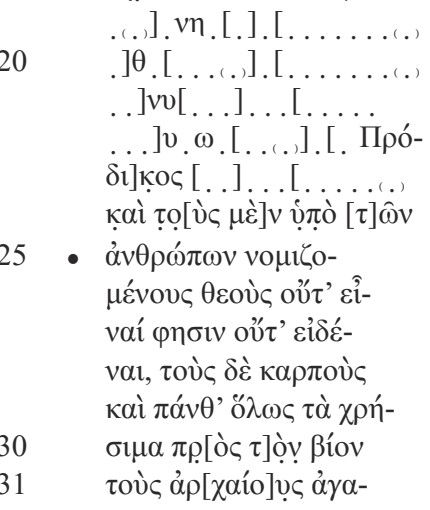

PHerc. 1428, cr. 4, col. 333 (= fr. 19) =O Bodl. Libr. Ms. Gr. Class. c. 5, fol. 1224 $(E, a)=N^{p c}$ fr. 19: $N^{a c}$ fr. $17\left(9^{\text {inf }}\right)=V H^{2}$ II 6 (= IPPH VIII 28 bis; XI 57bis; XXXIII $155=$ test. 72 Mayhew $=$ deest Dox. Graec., DK, Untersteiner et Winiarczyk) || 14;

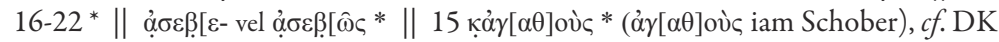
84 B 2 || 15-18* (cf. Philodemus Piet., PHerc. 1077 N, col. 19 Obbink; Script. inc.

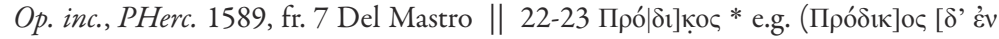

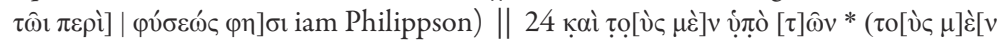

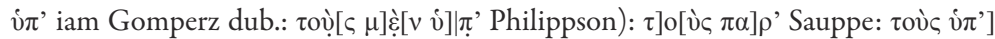

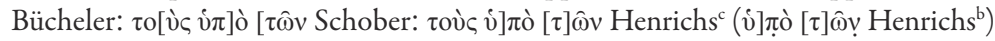

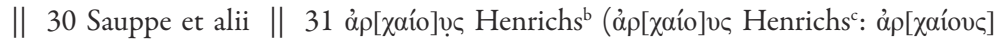

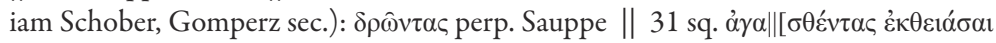
Schober e.g., acc. Henrichs ${ }^{c}(\dot{\alpha} \gamma \alpha \|[\sigma \theta \dot{\varepsilon} v \tau \alpha \Lambda$, iam Gomperz dub. in app.): $\dot{\alpha} \gamma \alpha \|[\theta \dot{\alpha}$

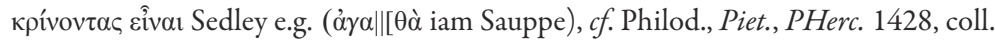
II 28-III 13 Henrichs $^{\mathrm{a}}$ (= DK 84 B 5 ${ }^{\mathrm{I}}$ ), de quo Henrichs ${ }^{\mathrm{b}}$, pp. 115-123; etiam DK 84 B 5 [II-IV]

(...) impious/to be impious/impiously (...). And Prodicus (?) [and] Diagoras maintain that $[$ the] gods are always good; Critias as well says that God (...) and besides Prodicus (...), on the one hand, says that the gods in which men believe neither exist nor are known by them, on the other hand [he proclaims himself convinced that] the ancients, as a sign of admiration, [worshipped as gods] the fruits of the earth and, in general, all the things useful for their life $(. .$.

The other testimonium of PHerc. 1428 to be examined is located in the section of Philodemus' On Piety specifically devoted to the criticism of Stoic theology. On the basis of my reconstruction of the roll, ${ }^{17}$ the section concerning the theology of Zeno of Citium has been unfortunately lost; however, it can be summarily inferred through a comparison with the parallel text of 
Cicero. ${ }^{18}$ Col. 347 (T2a) and most of col. 348 (T2b) are to be referred to Cleanthes, not to Zeno, as Hans von Arnim thought. ${ }^{19}$ Nevertheless, the theological positions of the two Stoic philosophers seem to coincide in some critical respects, when we consider that both try to interpret the gods in an allegorical sense, namely as a symbol of physical principles or elements, ${ }^{20}$ and to make God the Logos that steers the universe. ${ }^{21}$ In the last part of col. 348, the doxographical section on Persaeus begins, which is continued in the following column (T2c). No doubt, Philodemus' account is more detailed than the parallel testimonium by Cicero, ${ }^{22}$ and, in comparison to the latter, it explicitly cites Prodicus as the source (or at least one of the sources) of Persaeus' theology. The new edition I am going to provide considerably alters the philosophical approach to this piece of evidence. Indeed, Mayhew found in Albert Henrichs' old readings decisive textual backing to make Persaeus (and consequently Prodicus as well) a radical atheist, that is to say, an abso-

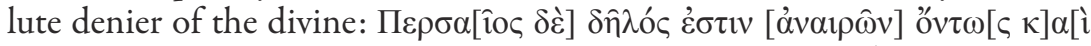

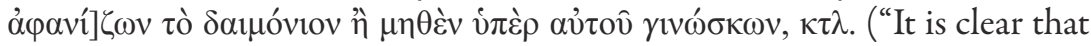
Persaeus is really abolishing and removing the divine or recognizing nothing about it, etc.").$^{23}$ Now, according to this reconstruction of the text, there is, first of all, an obvious contradiction between the idea that God does not exist and the opinion that nothing can decisively be said about God (that is, strictly speaking, whether he even exists or not). But, apart from that, the thesis of Persaeus' atheism fails in the light of my new readings (T2b). ${ }^{24}$ If they are plausible, Persaeus, after his master Zeno, ${ }^{25}$ believed there to be

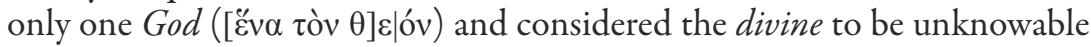

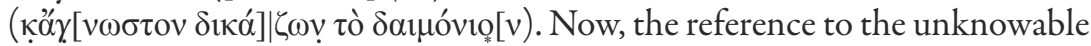
nature of the divine rather than of God guarantees, in my view, the strongly epistemological nature of the second part of this piece of evidence. In other

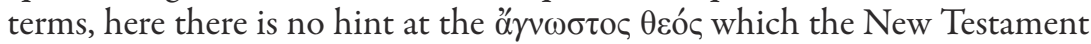
speaks about with regard to Paul's speech to the Athenians on the Areopagus. $^{26}$ Therefore, the Herculanean testimonium does not allude to the worship of a nameless God, but to the philosophical (as opposed to popular) way of acknowledging and conceiving the divine as a whole. For this reason,

18. Cicero ND I [14] 36.

19. SVF I 168 and 170.

20. On this point see at least Ramelli \& Lucchetta 2004 and Most 2016.

21. SVF I 531. On Stoic theology see, among others, Frede 2005 and Salles 2009.

22. Cicero ND I [15] 38.

23. T71 Mayhew (I give here the text as printed and translated by R. Mayhew).

24. My new text will appear in Mansfeld \& Runia (forthcoming) and in Ch. Vassallo, The

Presocratics in the Herculaneum Papyri: Texts, Translations, and Commentary, Berlin-Boston

(Studia Praesocratica), in preparation, s.v. Prodicus Ceus.

25. SVF I 164.

26. Act.Ap. 17, 23. Cf. Norden 2002 p. 133-258; Henrichs 1994 p. 29-39. 
as we read in col. 348 (T2c), the Stoic philosopher found Prodicus' theological stance convincing. It also becomes evident that the sophist trusted in a God whose nature was not definable with certainty by human language ( $\theta \varepsilon \dot{c} \varsigma$

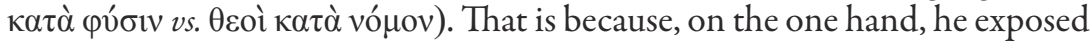
the merely materialistic and utilitarian origin of traditional worship and, on the other, outlined its gradual passage from fetishism to anthropomorphism. Indeed, it is clear enough that in T2c there is an outline of the evolution of religion in two stages: at the first stage, men deified all that was useful to their

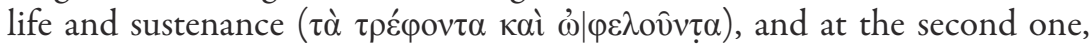

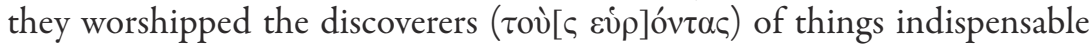
to human life as gods. The absence of the second stage in $\mathbf{T} 1$ and in the testimonia of Cicero (T73 Mayhew), Sextus (T74-75 Mayhew), and Themistius (T77 Mayhew) has led some scholars to believe that only Persaeus, and not Prodicus, theorized this stage. ${ }^{27}$ But Philodemus' text does not allow this reading: it clearly assigns the theory of the two stages to Prodicus. ${ }^{28}$ Thus, it is a fair assumption to consider Prodicus the first ancient philosopher to have studied the religious phenomenon from an evolutionary point of view, ${ }^{29}$ yet without embracing any form of 'atheism' in the modern sense of the term.

T2a. Philod. Piet., PHerc. 1428, col. 347 Vassallo (= col. I Henrichs)

\author{
'Амро-] $\|$

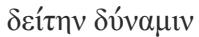

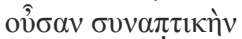

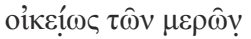

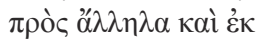 \\ 5

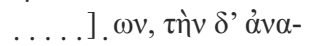

27. Pease 1955-1958 I, p. 261.

28. Therefore, I agree with the arguments of Nestle 1908 p. $556 \mathrm{ff}$. and 1936 p. $160 \mathrm{ff}$., later accepted by Henrichs 1975 p. 107-119 and now by Mayhew 2011 p. 180-181, who observes that "Philodemus records Persaeus' evaluation not simply of the views of Prodicus, but of what was written by Prodicus ( $\tau \grave{\alpha}[\ldots]$ i.. Persaeus had a copy of (at least a portion of) some book or speech of Prodicus (perhaps On Nature or Horai)." Moreover, this interpretation distinguishes in a certain sense Prodicus from Euhemerus (who theorizes only the deifying of powerful men) and better explains the words of Sextus in T75 Mayhew, where the two theories are compared.

29. For papyrological reasons (immediately after col. 349 there is a lacuna of several columns by my reckoning), I cannot follow Henrichs' reading 1975 p. 121, according to whom Prodicus is the subject of the beginning of col. IV Henrichs (= col. 356 Vassallo)

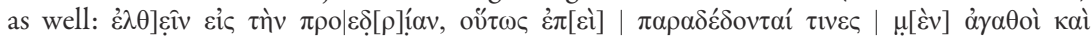

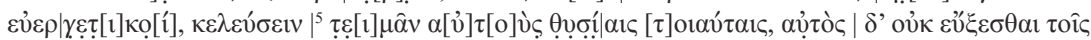

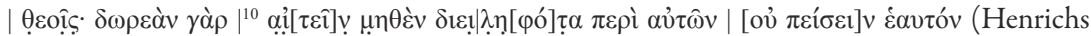
1974 p. 14-15). But we cannot rule out that this is the conclusion of the exposition of Persaeus' theology, inspired by Prodicus (and perhaps other ancient authors). The striking length of the testimonium to Persaeus suggests that Philodemus' source in turn tried to reconstruct the sources of Persaeus' On Gods, of which, on the other hand, we have knowledge only through this Herculanean piece of evidence. 


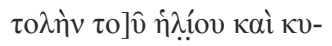

$\kappa \lambda \mathrm{o \tau \varepsilon ] \rho \eta ি} \pi \varepsilon \rho i ́ o \delta[o] \underline{~}$

'A $\pi \dot{\lambda} \lambda \lambda] \omega v \alpha, \tau o ̀ ~ \delta \dot{\varepsilon} \pi v \varepsilon \varepsilon[\hat{v}-$

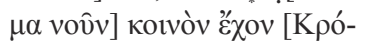

10

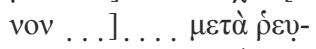

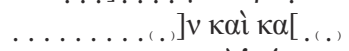

$\ldots \ldots \ldots \ldots, \kappa] \alpha \grave{~}{ }^{\mathrm{P} \varepsilon} \alpha[v$

15

$\ldots \ldots \ldots \ldots . .[\ldots \ldots . .$.

.......... [.

$\ldots \ldots \ldots \ldots .[\ldots$

...].[.]...[....]. [.

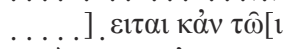

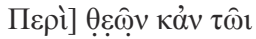

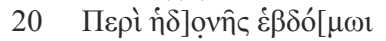

$\ldots . . ..] \mu \varepsilon$ [...]. o[ .....

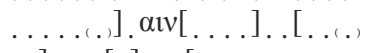

..]. 1 .[.] $\mu \varepsilon v[$

$\ldots . . ..] . \omega \mathrm{t} \alpha[.] \alpha[\ldots .$.

25

.[....... ] $] v \varepsilon \kappa \alpha \sigma[\ldots$

$\eta \omega \tau \sigma_{0} \varepsilon[\ldots . .] ..[\ldots .$.

$\alpha \tau \alpha \mu \varepsilon v[.] \mathrm{o} \sigma \delta[\ldots .$.

$\alpha \varepsilon \chi 0 \nu \tau \alpha[\ldots] \kappa \tau$.[.....

$\tau$ ì $\delta$ ' $\alpha \omega \omega[\ldots] .1 \sigma .[\ldots, \ldots$,

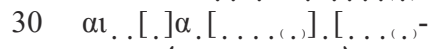

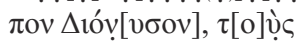

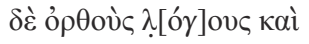

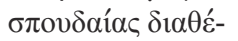

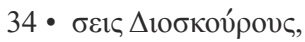

PHerc. 1428, cr. 5, pz. 2, col. 347 (= col. 1) = O Bodl. Libr. Ms. Gr. Class. c. 5, fol. $1218(G, a)=N$ col. $1(=$ col. 23$)=V H^{2}$ II $8(=$ Zeno $S V F$ I 168 et $170 ;$ Dox.Graec. p. 542-543) || 1 'A

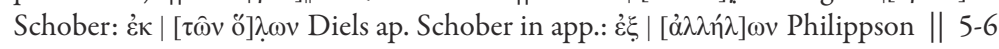

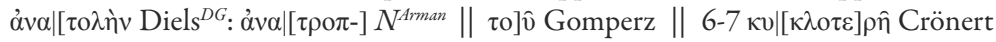

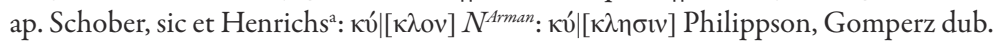

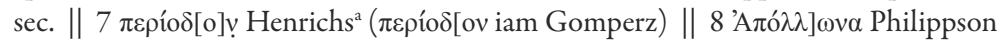
|| 8-10 Sedley e.g., conl. P.Derveni, coll. XIV-XV et Plato Crat. 396b3-7; 402a4-c3

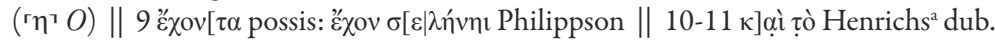

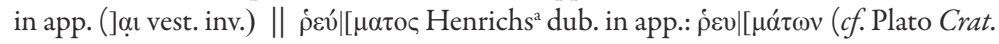

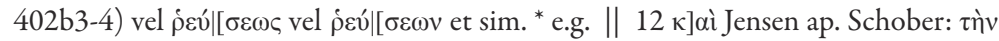
$\gamma \hat{n}]$ y perp. Philippson \|f fin. ${ }^{~ P \varepsilon ́ \alpha[v ~ P h i l i p p s o n ~ \| ~} 18 \pi$ o]ıî̃ $\alpha$ Schober (qui ante hoc

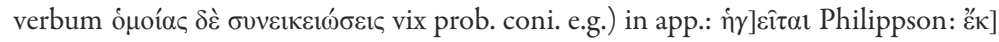

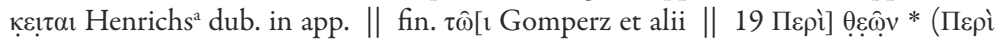
$\theta \varepsilon \hat{\omega}] v$ iam Schober, Philippson sec., conl. Cleanthes SVF I 481 et 543) || 20 Пврі̀

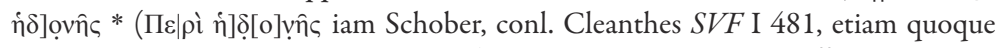

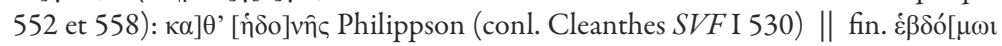




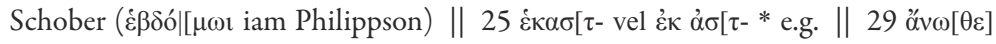

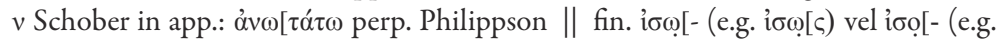

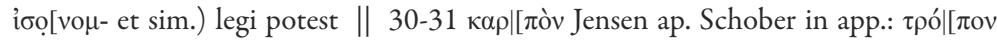

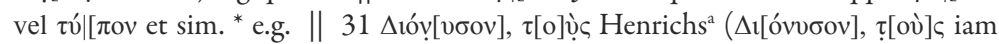

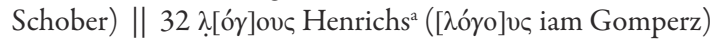

[(...) he (scil. Cleanthes) maintains that (the centre/harmony?) of the universe is] Aphrodite, since she is the power that properly joins together the parts to one another and [according to their analogies (?)], moreover [that] the rising of the $\operatorname{Sun}^{30}$ and its circular periodical movement [is] Apollo, while the (...) having a common (...) with the flux ${ }^{31}(.$.$) and (...) and [that] Rhea (...)$ and (...) [formulates such similarities (?)] in the treatise $[\mathrm{On}] \mathrm{Gods}$ and in the seventh book of that $[\mathrm{On}]$ Pleasure (...) everyone (?) [vel from the stars (?)] (...) what is on high (?) (...) [is] Dionysus, then [that] the right speeches and the virtuous dispositions of soul [are] the Dioscuri, (continues on)

T2b. Philod. Piet. PHerc. 1428, col. 348 Vassallo (= col. II Henrichs)

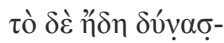

$\theta \alpha \imath \lambda \varepsilon ́ \gamma \varepsilon ı v \Lambda \underline{\delta} \delta \alpha v$

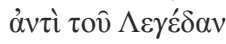

[..]... $\sigma \pi 0 v \delta \alpha i ́ \alpha v$

$5 \dot{\zeta}[\eta \dot{\tau} \tau] \eta \boxminus[\sigma] v \kappa \alpha \theta[\theta] \varepsilon \lambda \varepsilon \hat{\imath} v$

$\ldots \delta \eta[. ..] \ldots \varepsilon \varepsilon^{3} \gamma \varepsilon-$

$v[\varepsilon \sigma \ldots . . . . . .[.] \varepsilon i \tau \alpha \iota$

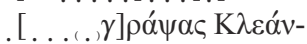

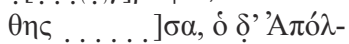

$10 \lambda \omega v \ldots ..] . \varepsilon \ldots \sigma v[\ldots] \varepsilon$

.......]. $\varepsilon \gamma .$. [.].

$\ldots . . . ..] \theta \cos \varsigma, \alpha \sigma$

$\ldots \ldots \ldots$. . . o $\operatorname{cov}[$.

$\ldots \ldots().] \delta . v[.] \varepsilon . \mathrm{ov}$

15

..........].].].] $v \theta$

$\ldots \ldots \ldots$

$\ldots \ldots \ldots$

$\ldots \ldots . . . . . . .$.

20

[....].[.] $\alpha \sigma \sigma[$

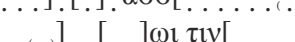

]$\sigma \alpha[\ldots]$

. $] \sigma \alpha . ..] .[.] v,[\ldots .$.

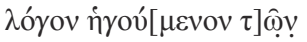

30. According to Cleanthes, the Sun was the i $\gamma \varepsilon \mu$ ovikóv of the cosmos. Cf. Cleanthes SVF I 499 (= Arius Didymus fr. 29 Diels, p. 465 ap. Eusebius P.E. XV 15, 7).

31. Scil. of the stars? 
$25 \dot{\varepsilon} v[\tau] \hat{\omega} 1 \kappa o ́ \sigma \mu[\omega 1 \ldots \ldots .$.

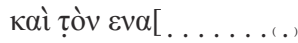

$\pi \mathrm{ov} \alpha \pi \mathrm{o} \tau .[\ldots \ldots \ldots)$

$\theta \alpha 1 . ~ \Pi \varepsilon \rho \sigma \alpha[\hat{\imath} о \varsigma \delta \dot{\varepsilon} \delta] \hat{\eta}-$

-

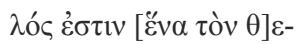

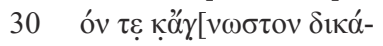

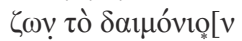

$\hat{\eta} \mu \eta \theta \dot{\varepsilon े v}$ i $\pi \dot{\varepsilon} \rho \alpha \hat{v}-$

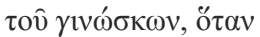

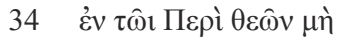

PHerc. 1428, cr. 5, pz. 2, col. 348 (= col. 2) = O Bodl. Libr. Ms. Gr. Class. c. 5, fol. 1219 $(G, b)=N$ col. $2\left(=\right.$ col. 24) $=V H^{2}$ II $9(=I P P H$ XXXIII $156=$ Prodicus T72 Mayhew $=$ DK 84 B $5=$ Dox.Graec., p. $544=$ Persaeus $S V F$ I $448=$ Cleanthes SVF I 531)

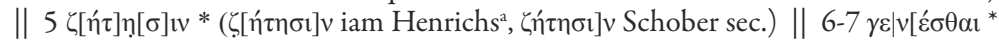

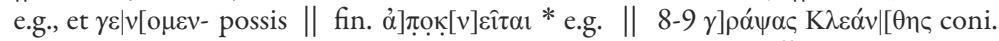

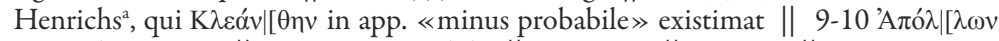

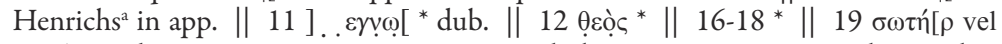

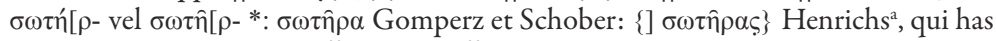

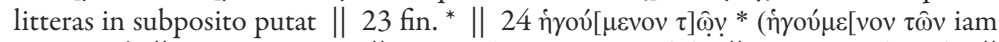
Gomperz) || $25 *$ Gomperz || 26 हैva leg. Gomperz dub. || 28 Spengel et alii \|

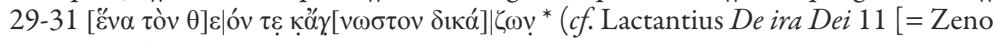
SVF I 164 (I)]; praes. Philodemus Piet., PHerc. 1428, col. 10, 8-15 [= Zeno SVF I

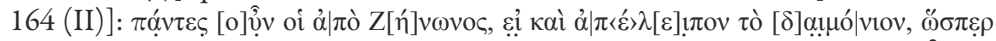

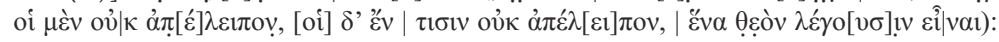

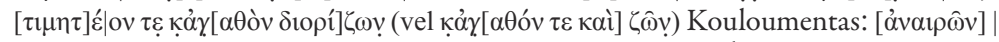

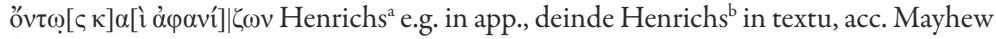

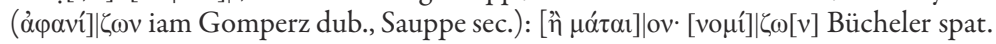

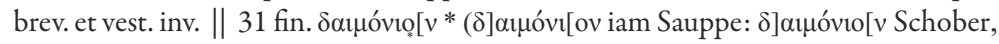

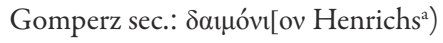

furthermore [he (scil. Cleanthes) maintains that its (scil. of the world/cos$\left.\operatorname{mos}^{32}\right)$ ] being already provided with the capacity to read/speak [is] Leda instead of Legeda (...) put down/reduce (?) a good inquiry (...) become (?) well (...) [is feared (?)] (...) Cleanthes having written (...), and Apollo (...) God (?) (...) deliver/deliverer (...) the Logos steering the things in the universe (...) and [maintaining that] the (...).

[Then] Persaeus clearly considers God [one] and the divine unknowable, or such that nothing can be said about it, when in the treatise On Gods, not (continues on)

32. So David Sedley per litteras. 
T2c. Philod. Piet., PHerc. 1428, col. 349 Vassallo (= col. III Henrichs) $\dot{\alpha} \pi \dot{i} \theta \alpha v \alpha \lambda \varepsilon \varepsilon^{\prime} \eta$

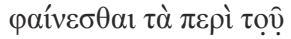
$\tau \alpha \grave{~ \tau \rho \varepsilon ́ \varphi o v \tau \alpha ~ \kappa \alpha i ̀ ~}$

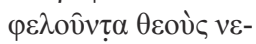

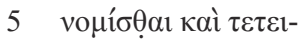
$\mu \hat{\eta} \sigma \theta[\alpha l] \pi \rho \hat{\omega} \tau[\mathrm{o}] v \dot{v}-$

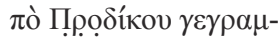

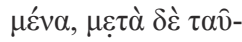

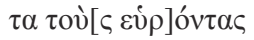

10 ì ì $\tau \grave{\alpha} \varsigma \alpha \alpha^{\prime} \lambda \lambda \alpha \varsigma \tau \tau^{\prime} \chi v \alpha \varsigma$

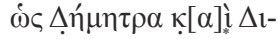

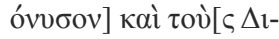

14 обкои́ $]$ ov $[\varsigma \ldots \ldots$. desunt versus 9

$24 \quad \ldots . . \alpha[$...].[........

$25 \alpha \xi \varepsilon i[\ldots] . \alpha v[\ldots] .[\ldots \ldots)$ $\varepsilon 1 \kappa \alpha[, .],, v .[\ldots \ldots$, $\gamma \varepsilon \tau \alpha[.] \pi \alpha[\ldots . .(\cdot)$

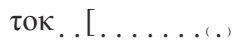
.]. $\varepsilon[$ $\mathrm{ov \tau}[\ldots] \mathrm{.} . .[\ldots .$. $\eta \sigma \varepsilon 1 v \tau \alpha[\ldots, \kappa] \alpha \underline{i}$

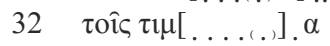

PHerc. 1428, cr. 5, pz. 2, col. $349(=$ col. 3) = O Bodl. Libr. Ms. Gr. Class. c. 5, fol. $1220(G, c)=N$ col. $3(=$ col. 25$)=V H^{2}$ II $10(=I P P H$ XXXIII $157=$ Prodicus T72

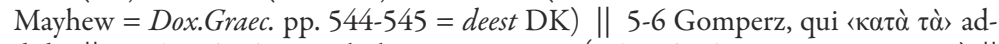

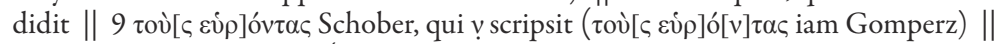

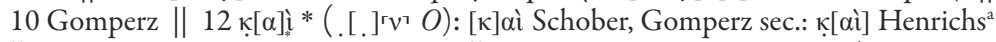

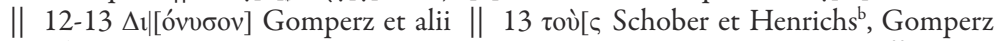

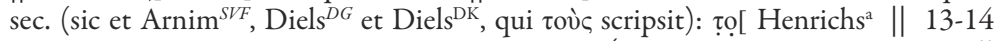

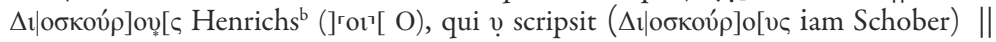

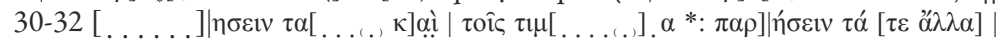

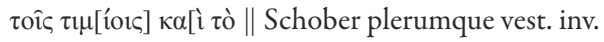

unconvincing ${ }^{33}$ he says to appear what was written by Prodicus about the fact that nourishing and useful things were first believed and honoured as gods, successively those who discovered foods or shelters or the other crafts such as Demeter and Dionysus and the Dioscuri (...) and to/with the (...)

33. Obviously, the adjective $\alpha^{\prime} \pi i^{\prime} \theta \alpha v \alpha$ is to be connected to the $\mu \grave{\eta}$ with which the previous column ends. 


\section{Conspectus siglorum}

$\mathrm{P}$
$N$
$O$
$V H^{2}$

PHerc. 1428

apographum Neapolitanum $\left[N^{\mathrm{pc}}:\right.$ lectio $N$ post correctionem / $N^{\text {ac }}$ : lectio $N$ ante correctionem] apographum Oxoniense

Herculanensium Voluminum quae supersunt. Collectio altera, tom. II, Neapoli: e Museo publico, 1863, p. 1-22

Diels $^{D G}=$ Dox. Graec. $=$ Diels 1965; Diels ${ }^{\mathrm{DK}}=\mathrm{DK}=$ Diels \& Kranz 1951-1952; Del Mastro = Del Mastro 2008; Gomperz $=$ Gomperz 1866; Henrichs ${ }^{a}=$ Henrichs 1974; Henrichs $^{\mathrm{b}}=$ Henrichs 1975; Henrichs ${ }^{\mathrm{c}}=$ Henrichs 1976; IPPH = Vassallo 2016; Kouloumentas $=$ Stavros Kouloumentas per litteras; Mayhew = Mayhew 2011; Philippson $=$ Philippson 1920; Sauppe $=$ Sauppe 1864; Schober $=$ Schober 1988; Sedley = David Sedley per litteras; Spengel = Spengel 1864; Untersteiner = Untersteiner 1967; Winiarczyk $=$ Winiarczyk 1981; Arnim $^{S V F}=S V F=$ Arnim 1903-1924; ${ }^{*}=$ ego.

\section{Conspectus signorum}

... litterarum vestigia

$\alpha \beta \gamma$ litterae dubiae quae aliter legi possunt

... litterarum superposita vel subposita vestigia ab editore recognita et

loco suo collocata

$[\alpha \beta \gamma]$ litterae ab editore suppletae

$\{\alpha \beta \gamma\}$ litterae $a b$ editore deletae

$\langle\alpha \beta \gamma\rangle$ litterae ad editore additae

$[\alpha \beta \gamma]$ litterae a librario deletae

' $\alpha \beta \gamma^{\prime}$ litterae supra lineam scriptae a librario additae

$\ulcorner\alpha \beta \gamma\urcorner$ litterae alterutrius vel utriusque apographi

$\llcorner\alpha \beta \gamma\lrcorner$ litterae a fonte gemino ab editore suppletae

$\alpha \beta \gamma$ litterae apographi ab editore mutatae

[... ] litterae deperditae

[... ] una vel duae litterae deperditae

$\|$ finis columnae

$>$ diple obelismene

†. . . † locus corruptus (cruces desperationis)

$>$ signum quo librarius spatium explevit

${ }^{\top}$ spatium vacuum

- signum spatii vacui supra lineam a librario additum

I spatiolum

- signum stichometricum 


\section{BIBLIOGRAPHY}

Arnim, H. von 1903-1924 (éd.) : Stoicorum Veterum Fragmenta, 4 vol., vol. IV conscripsit M. Adler, Stuttgart, 1903-1924.

Brancacci, A. 1985-1986 : « La théologie d'Antisthène », Philosophia, 15-16 (1985-1986), p. 218-230.

Del Mastro, G. 2008 : «Il PHerc. 1589 e una nuova testimonianza su Temista e Leonteo », Cronache Ercolanesi, 38 (2008), p. 221-228.

Diels, H. 1965 (éd.) : Doxographi Graeci, Berlin, 1965 [1879].

Diels, H \& W. Kranz 1951-1952 (éd.) : Die Fragmente der Vorsokratiker, 1-3, Berlin, 1951-1952.

Frede, M. 2005 : « La théologie stoïcienne », dans G. Romeyer Dherbey (dir.) \& J.-B. Gourinat (éd.), Les Stoïciens, Paris, 2005, p. 213-232 (Bibliothèque d'Histoire de la Philosophie. Nouvelle série).

Giannantoni, G. 1990 (éd.) : Socratis et Socraticorum Reliquiae (= SSR), 4 vol., Napoli, 1990 (Elenchos, 18).

Gomperz, T. 1866 (éd.) : Philodemus, Über Frömmigkeit, Leipzig, 1866 (Herkulanische Studien, 2).

Henrichs, A. 1974 (éd.) : « Die Kritik der stoischen Theologie im PHerc. 1428 », Cronache Ercolanesi, 4 (1974), p. 5-32.

- 1975 : « Two Doxographical Notes : Democritus and Prodicus on Religion », Harvard Studies in Classical Philology, 79 (1975), p. 93-123.

- 1976: «The Atheism of Prodicus », Cronache Ercolanesi, 6 (1976), p. 15-21.

- 1984: «The Sophists and Hellenistic Religion : Prodicus as the Spiritual Father of the Isis Aretologies », Harvard Studies in Classical Philology, 88 (1984), p. 139-158.

- 1994: « Anonymity and Polarity : Unknown Gods and Nameless Altars at the Areopagos », Illinois Classical Studies, 19 (1994), p. 27-58.

Long, A. \& D. N. Sedley 1987 (éd.) : The Hellenistic Philosophers, 2 vols., Cambridge, 1987.

Mansfeld, J. 2013 : «Detheologization : Aëtian Chapters and their Peripatetic Background », Rhizomata, 1/2 (2013), p. 330-362.

Mansfeld, J. \& D. T. Runia forthcoming (éd.) : Aëtiana: The Method and Intellectual Context of a Doxographer, vol. V, Leiden-Boston, forthcoming (Philosophia Antiqua).

Mayhew, R. 2011 (éd.) : Prodicus the Sophist: Texts, Translations, and Commentary, Oxford, 2011.

Most, G. W. 2016 : « Allegoresis and Etymology », dans A. Grafton \& G. W. Most (éd.), Canonical Texts and Scholarly Practices : A Global Comparative Approach, Cambridge, 2016, p. 52-74.

Nestle, W. 1908 : « Bemerkungen zu den Vorsokratikern und Sophisten », Philologus, 67 (1908), p. 531-581.

- 1936: «Die Horen des Prodikos », Hermes, 71 (1936), p. 151-170.

Norden, E. 2002 : Agnostos Theos / Dio ignoto : Ricerche sulla storia della forma del discorso religioso, a cura di C. O. Tommasi Moreschini, Brescia, 2002 (Letteratura cristiana antica. Studi) [1913]. 
Pease, A. S. 1955-1958 (éd.) : Cicero, De natura deorum, 2 vols., Cambridge (Mass.), 1955-1958.

Philippson, R. 1920 : «Zu Philodems Schrift über die Frömmigkeit », Hermes, 55/3 (1920), p. 225-278; « Zu Philodems Schrift über die Frömmigkeit. IV. Die Philosophenkritik », Hermes, 55/4 (1920), p. 364-372.

RAmelli, I. \& G. Lucchetta 2004 : Allegoria, vol. I, L'età classica, introduz. e cura di R. Radice, Milan, 2004 (Pubblicazioni del Centro di ricerche di metafisica. Temi metafisici e problemi del pensiero antico. Studi e testi, 98).

Runia, D. T. 1996 (éd.) : « Atheists in Aëtius : Text, Translation and Comments on De placitis 1, 7, 1-10 », Mnemosyne, s. IV, 49/5 (1996), p. 542-576.

Salles, R. 2009 (éd.) : God and Cosmos in Stoicism, Oxford, 2009.

Sauppe, H. 1864 (éd.) : Philodemus, Commentatio de Philodemi libro qui fuit de pietate, Goettingae, 1864.

Schober, A. 1988 (éd.) : « Philodemi Depietate, Pars prior », Cronache Ercolanesi, 18 (1988), p. 67-125.

Sedley, D. N. 2013 : « The Atheist Underground », dans V. Harte \& M. Lane (éd.), Politeia in Greek and Roman Philosophy, Cambridge, 2013, p. 329-348.

Spengel, L. 1864 : «Aus den Herculanischen Rollen : Philodemus Пepi

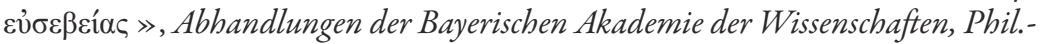
hist. Kl., 10/1 (1864), p. 127-167.

UntersteIner, M. 1967 (éd.) : Sofisti : testimonianze e frammenti, 4 vol., $2^{\mathrm{e}}$ éd., Firenze, 1967 (Biblioteca di Studi Superiori / Filosofia antica, 4-7).

Vassallo, C. 2016 (éd.) : «A Catalogue of the Evidence for Presocratics in the Herculaneum Papyri » (=IPPH), Archiv für Papyrusforschung und verwandte Gebiete, 62/1 (2016), p. 78-108.

- 2017 (éd.) : « La 'sezione presocratica' del De pietate di Filodemo : una nuova ricostruzione : Praesocratica Herculanensia X (Parte I) », Archiv für Papyrusforschung und verwandte Gebiete, 63/1 (2017), p. 171-203.

- 2018: «The 'pre-Socratic Section' of Philodemus' On Piety: A New Reconstruction : Praesocratica Herculanensia X (Part II) », Archiv für Papyrusforschung und verwandte Gebiete, 64/1 (2018), in press.

— forthcoming a : « Anaxagoras from Egypt to Herculaneum : A Contribution to the History of Ancient Atheism », dans C. Vassallo (éd.), Presocratics and Papyological Tradition, Proceedings of the International Workshop held at the University of Trier, 22-24 September 2016, Berlin-Boston, De Gruyter, forthcoming.

— forthcoming b : «Feuer und göttliche Dialektik bei Heraklit : Neue Lesungen in PHerc. 1428, Kol. 330 (olim Fr. 17) : Praesocratica Herculanensia IX », Mnemosyne, 2018, in press (preprint on BrillOnline.com, DOI : 10.1163/1568525X12342391).

Winiarczyk, M. 1981 (éd.) : Diagorae Melii et Theodori Cyrenaei Reliquiae, Leipzig, 1981 (Bibliotheca scriptorum Graecorum et Romanorum Teubneriana).

- 1991 (éd.) : Euhemerus, Euhemeri Messenii Reliquiae, Stuttgart, 1991 (Bibliotheca scriptorum graecorum et romanorum teubneriana).

Wittgenstein, L. 1995 : Tractatus logico-philosophicus e Quaderni 1914-1916, a cura di A. G. Conte, nuova ed., Torino, 1995 (Biblioteca studio, 18). 